\title{
Influence of low protein diets on gene expression of digestive enzymes and hormone secretion in the gastrointestinal tract of young weaned piglets*
}

\author{
Zhi-mei TIAN, Xian-yong MA ${ }^{\dagger}$, Xue-fen YANG, Qiu-li FAN, Yun-xia XIONG, \\ Yue-qin QIU, Li WANG, Xiao-lu WEN, Zong-yong JIANG ${ }^{\dagger+}$ \\ (State Key Laboratory of Livestock and Poultry Breeding, Ministry of Agriculture Key Laboratory of Animal Nutrition and Feed Science in \\ South China, Guangdong Public Laboratory of Animal Breeding and Nutrition, Guangdong Key Laboratory of Animal Breeding and \\ Nutrition, Institute of Animal Science, Guangdong Academy of Agricultural Sciences, Guangzhou 510640, China) \\ †E-mail: 407986619@qq.com; jiangz28@qq.com \\ Received May 19, 2016; Revision accepted Aug. 4, 2016; Crosschecked Sept. 10, 2016
}

\begin{abstract}
To investigate dietary protein level effects on digestive mechanisms, weaned piglets were fed for $45 \mathrm{~d}$ with diets containing $20 \%, 17 \%$, or $14 \%$ crude protein (CP) supplemented to meet requirements for essential amino acids. This article describes the influence of dietary protein on gastrointestinal hormones and expression of an array of digestive enzymes in the gastrointestinal tract and pancreas. Results indicated that there were no significant differences in expression of enzymes involved in carbohydrate digestion, except for maltase in the duodenum. In the jejunum, amylase expression in pigs fed $20 \%$ CP was much higher than that in pigs fed other diets $(P<0.05)$ and maltase expression in those fed $17 \% \mathrm{CP}$ was higher than that in other treatments $(P<0.05)$. Although there were no remarkable differences in expression of aminopeptidase in the small intestine or carboxypeptidase in the pancreas $(P>0.05)$, there was a trend towards higher expression of various proteases in pigs fed $17 \% \mathrm{CP}$. The duodenal expression of enteropeptidase in diets with $14 \%$ and $17 \%$ CP was significantly higher than that with $20 \% \mathrm{CP}(P<0.05)$, but treatment differences did not existed in jejunum $(P>0.05)$. The expression of GPR93 as a nutrient-responsive $\mathrm{G}$ protein-coupled receptor in $14 \%$ and $17 \%$ CP diets was significantly higher than that in $20 \%$ CP diet in the small intestine $(P<0.05)$. The expressions of genes for pancreatic enzymes, lipase and elastase, were significantly higher in pigs fed diets with low $\mathrm{CP}$, while similar trends occurred for carboxypeptidase, chymotrypsin and amylase. Conversely, the gastric expressions of pepsinogen A and progastricsin were lower with the $17 \%$ CP diet. Differences between treatments were found in the gastric antral contents of cholecystokinin and somatostatin: both increased in pigs fed $17 \% \mathrm{CP}$, accompanied by decreased content of motilin, which was also seen in plasma concentrations. These patterns were not reflected in duodenal contents. In general, $17 \%$ dietary CP was beneficial to the digestion of nutrient substance in the gastrointestinal tract.
\end{abstract}

Key words: Dietary protein, Piglet, Gastrointestinal tract, Pancreas, Digestion, Hormone http://dx.doi.org/10.1631/jzus.B1600229 CLC number: S821.5

\footnotetext{
Corresponding authors

* Project supported by the National Basic Research Program (973) of China (Nos. 2013CB127301 and 2013CB127304), the Guangdong International Science and Technology Cooperation Program (No. 2014A050503049), the China Agriculture Research System (No. CARS-36), and the Science and Technology Program of Guangdong Province (Nos. 2013A061401020 and 2016A020210041), China (1) ORCID: Zhi-mei TIAN, http://orcid.org/0000-0002-1738-7454 (C) Zhejiang University and Springer-Verlag Berlin Heidelberg 2016
}

\section{Introduction}

Dietary proteins perform a wide range of nutritional and biological functions. In addition to their nutritional role in supplying amino acids for endogenous protein synthesis, they play a part in regulating feed intake and glucose and lipid metabolism in order 
to sustain growth, development, and multiplication of organisms (Len et al., 2009; Jahan-Mihan et al., 2011; Peng et al., 2016). Within the gastrointestinal tract (GIT), the level of protein has a major impact on digestion and absorption, and their digestive products affect several regulatory functions by interacting with receptors releasing hormones, affecting stomach emptying, gastrointestinal (GI) transport and absorption of nutrients (Leray et al., 2003; Jahan-Mihan et al., 2011; Yang et al., 2011; He et al., 2016). The amount of dietary protein is a major issue impacting the economy and environment, and therefore this study was principally focused on the importance of dietary protein levels on the regulation of amino acid, glucose and lipid metabolism in the GIT, along with feed intake.

The early stage of growth after weaning is considered to be most efficient in the conversion of nutrients to animal tissue (Kendall et al., 2008). Digestive enzymes and GI hormones play essential roles in nutritional digestion and absorption, and hence expressions of gut enzymes involved in carbohydrate, protein and fat digestion were examined here during this phase of maximal growth. Bikker et al. (2006) pointed out that dietary protein level did not affected maltase, sucrase or aminopeptidase $\mathrm{N}$ activity in jejunum, but Pinheiro et al. (2013) reported that dietary protein restriction increased disaccharidase activity such as lactase and sucrase in the small intestine. Yue and Qiao (2008) demonstrated that reducing dietary crude protein (CP) concentration from $23.1 \%$ to $17.2 \%$, but not partial reduction to $18.9 \%$, changed gut morphology and reduced disaccharidase activities in the small intestine. Some studies indicate that pancreatic enzymes were positively associated with dietary protein level and low dietary protein inhibited synthesis of pancreatic enzymes and pancreatic growth; little is known of the possible influence of low protein diets on pancreatic lipase (Lindemann et al., 1986; Makkink et al., 1994).

Dietary protein level also affects GI hormones, digestion and nutrient uptake (Chaudhri et al., 2006). High protein diets increased cholecystokinin (CCK) release and pancreatic protease secretion (Green et al., 1986), but Shi et al. (1997) and Leray et al. (2003) argued that a low-protein diet inhibited gastric emptying through modulation of CCK release and gastric muscle sensitivity to CCK, and postprandial plasma levels of CCK were increased significantly. Pancreatic amylase production was suppressed by endogenous CCK (Hara et al., 2001). Somatostatin (SS), a GI motility regulator, also inhibits the release of gut hormones including gastrin, insulin, CCK, and motilin (MLN) and slows gastric emptying, gallbladder contraction, and small intestinal segmentation (Ling et al., 1973; Patel, 1999; Morisset et al., 2000). The $\mathrm{G}$ protein-coupled receptor, GPR93, regulates mucosal cell proliferation and differentiation and the extent of hormonal secretion triggered by digestive products in the lumen. Lower levels of GPR93 occur in the gastric mucosa than in the intestinal mucosa (Choi et al., 2007). Pancreatic lipase, produced by pancreatic acinar cells, efficiently hydrolyzes triglycerides to free fatty acids and accounts for the bulk of fat digestion in animals (Lowe, 1994; Xiao et al., 2013). There appears to be little known about the effect of low protein diets on the secretion of MLN and SS, and mRNA expression of GPR93 and pancreatic lipase. According to previous researches, we presumed that decreasing adequately dietary $\mathrm{CP}$ was sufficient for the requirement of growth performance and more beneficial to a weaned piglet. The focus of the present study was to explore physiological and metabolic indices of GIT and pancreatic function, including expression of genes for digestive enzymes and secretion of selected hormones.

\section{Materials and methods}

\subsection{Animals and experimental treatments}

Cross-bred (Duroc $\times$ Landrace $\times$ Yorkshire) piglets were weaned at $28 \mathrm{~d}$ of age and the experiment started after a 7-d adaptation period. Eighteen piglets (initial body weight $(\mathrm{BW})$ is $(9.57 \pm 0.64) \mathrm{kg}$ ) were randomly assigned to three groups. Diets with $20 \%$, $17 \%$, and $14 \%$ CP were based on the National Research Council (NRC) recommendation (Committee on Nutrient Requirements of Swine, National Research Council, 2012), as shown in Table 1, and were supplemented with 4 essential amino acids (Lys, Met, Thr, and Trp) to meet the requirements of weaned piglets (Wu et al., 2015). Piglets were housed individually in cages and had free access to drinking water and their respective diets throughout the 45-d experimental period ( 35 to $80 \mathrm{~d}$ of age). 
Table 1 Composition and nutrient levels of diets

\begin{tabular}{|c|c|c|c|}
\hline \multirow{2}{*}{ Component } & \multicolumn{3}{|c|}{ Content $(\%)^{\mathrm{a}}$} \\
\hline & $14 \% \mathrm{CP}$ & $17 \% \mathrm{CP}$ & $20 \% \mathrm{CP}$ \\
\hline \multicolumn{4}{|l|}{ Ingredient } \\
\hline Corn & 71.80 & 66.50 & 63.70 \\
\hline Soybean meal & 13.40 & 18.80 & 19.80 \\
\hline Whey powder & 4.40 & 4.30 & 4.30 \\
\hline Fish meal & 1.50 & 4.00 & 9.00 \\
\hline Soybean oil & 4.10 & 2.60 & 0.80 \\
\hline Lys & 0.88 & 0.62 & 0.38 \\
\hline Met & 0.27 & 0.19 & 0.10 \\
\hline Thr & 0.33 & 0.21 & 0.09 \\
\hline Trp & 0.08 & 0.04 & 0.01 \\
\hline Calcium hydrophosphate & 1.15 & 0.74 & 0.00 \\
\hline Limestone & 0.79 & 0.70 & 0.52 \\
\hline Salt & 0.30 & 0.30 & 0.30 \\
\hline $1 \%$ premix compound $^{\mathrm{b}}$ & 1.00 & 1.00 & 1.00 \\
\hline Total & 100.00 & 100.00 & 100.00 \\
\hline \multicolumn{4}{|l|}{ Calculated nutrient content } \\
\hline $\mathrm{DE}(\mathrm{MJ} / \mathrm{kg})$ & 14.60 & 14.60 & 14.60 \\
\hline $\mathrm{CP}$ & 14.00 & 17.00 & 20.00 \\
\hline Total Ca & 0.70 & 0.71 & 0.69 \\
\hline Total P & 0.53 & 0.55 & 0.57 \\
\hline Arg & 0.75 & 0.91 & 1.09 \\
\hline His & 0.34 & 0.40 & 0.46 \\
\hline Ile & 0.49 & 0.60 & 0.70 \\
\hline Leu & 1.15 & 1.32 & 1.49 \\
\hline Lys & 1.23 & 1.23 & 1.23 \\
\hline Met + Cys & 0.68 & 0.68 & 0.68 \\
\hline Phe & 0.59 & 0.69 & 0.80 \\
\hline Thr & 0.73 & 0.73 & 0.73 \\
\hline Trp & 0.20 & 0.20 & 0.20 \\
\hline Val & 0.53 & 0.65 & 0.77 \\
\hline EAA/NEAA & 0.90 & 0.80 & 0.70 \\
\hline $\begin{array}{l}\text { Recommendation rate of } \\
\text { NRC }^{c}\end{array}$ & 0.80 & 0.80 & 0.80 \\
\hline
\end{tabular}

DE: digestible energy; CP: crude protein; EAA: essential amino acids; NEAA: non-essential amino acid; NRC: National Research Council. ${ }^{a}$ The values are expressed as percentage (\%), except for $\mathrm{DE}(\mathrm{MJ} / \mathrm{kg})$, EAA/NEAA and recommendation rate of NRC. ${ }^{\mathrm{b}}$ Premix provided these amounts of vitamins and minerals per kilogram on an as-fed basis: vitamin $\mathrm{A}, 10800 \mathrm{IU}$; vitamin $\mathrm{D}_{3}$, $4000 \mathrm{IU}$; vitamin $\mathrm{E}, 40 \mathrm{IU}$; vitamin $\mathrm{K}_{3}, 4 \mathrm{mg}$; vitamin $\mathrm{B}_{1}, 6 \mathrm{mg}$; vitamin $\mathrm{B}_{2}, 12 \mathrm{mg}$; vitamin $\mathrm{B}_{6}, 6 \mathrm{mg}$; vitamin $\mathrm{B}_{12}, 0.05 \mathrm{mg}$; biotin $0.2 \mathrm{mg}$; folic acid, $2 \mathrm{mg}$; niacin, $50 \mathrm{mg}$; D-calcium pantothenate, $25 \mathrm{mg}$; Fe, $100 \mathrm{mg}$ as ferrous sulfate; $\mathrm{Cu}, 150 \mathrm{mg}$ as copper sulfate; $\mathrm{Mn}, 40 \mathrm{mg}$ as manganese oxide; $\mathrm{Zn}, 100 \mathrm{mg}$ as zinc oxide; I, $0.5 \mathrm{mg}$ as potassium iodide; and $\mathrm{Se}, 0.3 \mathrm{mg}$ as sodium selenite. ${ }^{\mathrm{c}}$ Committee on Nutrient Requirements of Swine, National Research Council, 2012. * Reprinted from Wu et al. (2015)

\subsection{Slaughter and tissue collection}

Pigs were fasted overnight (about $12 \mathrm{~h}$ ), and then blood was collected by jugular venipuncture using heparin-coated vacutainer tubes immediately before slaughter. Samples were centrifuged for $15 \mathrm{~min}$ at $1000 \mathrm{~g}$ at $4{ }^{\circ} \mathrm{C}$. The plasma was aliquoted into 2 plastic vials and stored at $-80^{\circ} \mathrm{C}$. Pigs were electrostunned and then exsanguinated, and the small intestine and stomach were immediately dissected, emptied of contents and placed on ice. Segments ( $2 \mathrm{~cm}$ in length) of mid-duodenum and gastric antrum were fixed in $10 \%$ Bouin's solution and stored at $4{ }^{\circ} \mathrm{C}$ for $48 \mathrm{~h}$. In addition, $3 \mathrm{~cm}$ segments from the mid-jejunum and mid-duodenum were also immediately flushed with phosphate buffer saline (PBS) at $4{ }^{\circ} \mathrm{C}$ and frozen in liquid nitrogen in sterile Eppendorf tubes then held at $-80{ }^{\circ} \mathrm{C}$.

\subsection{Relative quantification of mRNA expression}

Total RNA was extracted from tissues (100 mg) with TRIzol Reagent (TaKaRa, Otsu, Japan) and dissolved in RNase-free water. RNA ( $1 \mu \mathrm{g})$ was reversetranscribed to complementary DNA (cDNA) using PrimeScript 1st Strand cDNA Synthesis Kit (TaKaRa) following the manufacturer's protocol (Chen et al., 2013).

Partial or full-length gene coding sequences were amplified from cDNA using oligodeoxynucleotide primers (Table 2) designed from porcine sequences in GenBank with Primer Premier 5.0 (Applied Biosystems, Carlsbad, CA, USA). Real-time polymerase chain reaction (PCR; Bio-Rad System) was performed in a total volume of $20 \mu \mathrm{l}$ containing $2 \mu \mathrm{l}$ of cDNA, $10 \mu 1$ SYBR Green $2 \times$ mix, $0.8 \mu 1$ (100 nmol/L) each of the forward and reverse primers. An initial denaturation step of $95^{\circ} \mathrm{C}$ for $2 \mathrm{~min}$ was followed by 39 cycles of $95{ }^{\circ} \mathrm{C}$ for $15 \mathrm{~s}, 30 \mathrm{~s}$ at the annealing temperature, and $72{ }^{\circ} \mathrm{C}$ for $30 \mathrm{~s}$. The housekeeping gene $\beta$-actin was used as an internal control for efficiency of reverse transcription. Data were quantified using the comparative cycle threshold $\left(C_{\mathrm{T}}\right)$ method. For each sample, data were normalized to $\beta$-actin, and the relative expression values for each gene were calculated using the $2^{-\Delta \Delta C_{\mathrm{T}}}$ method with efficiency correction and using one control sample as calibrator.

\subsection{Relative quantification of mRNA expression}

Freshly harvested tissue (100 mg) was rinsed with $1 \times$ PBS, homogenized in $1 \mathrm{ml}$ of $1 \times$ PBS, and stored overnight at $-20{ }^{\circ} \mathrm{C}$. After further lysis with two freeze-thaw cycles, the homogenates were centrifuged for $5 \mathrm{~min}$ at $5000 \mathrm{~g}, 2-8^{\circ} \mathrm{C}$ and supernatants were collected and assayed immediately. Also, aliquots were stored at $-80{ }^{\circ} \mathrm{C}$, and re-centrifuged before assay. Concentrations of CCK, SS, and MLN in antral and duodenal extracts and plasma were determined using commercial enzyme linked immunosorbent assay (ELISA) kits (CUSABIO, Wuhan, China). 
Table 2 Primers used for real-time PCR analysis

\begin{tabular}{|c|c|c|c|c|}
\hline Gene & Primer sequence $\left(5^{\prime} \rightarrow 3^{\prime}\right)$ & Size (bp) & Accession No. & $T_{\mathrm{M}}\left({ }^{\circ} \mathrm{C}\right)$ \\
\hline \multirow[t]{2}{*}{ Sucrase } & F: CGAGCAGATTCTTAGTGATGGAT & 189 & XM_005657098.1 & 55 \\
\hline & R: GCATAGTTGTCTCCAAGCCAGT & & & \\
\hline \multirow[t]{2}{*}{ Glucosidase F } & F: TGATGAAGTCTGGGTGGGTGTG & 183 & NM_001258385 & 65 \\
\hline & R: ATGTAGGCGAGTGAGCGGAA & & & \\
\hline \multirow[t]{2}{*}{ Amylase } & F: GGGCAGCGTTTATTCTCACTCA & 252 & NM_214195 & 65 \\
\hline & R: TCTCTTGCTTCTTCCCTGTTCC & & & \\
\hline \multirow[t]{2}{*}{ Maltase } & F: TGCCTTACCTCTACACGCTGATGC & 113 & XM_003475331 & 62 \\
\hline & R: GATTCACTGCCAGATTCCGTGCTAT & & & \\
\hline \multirow[t]{2}{*}{ Lactase } & F: GCTACCACCTAATACAGTAAACCTCCC & 235 & XM_003359430 & 55 \\
\hline & R: CCCACAGAAAGTCATCCCGAAA & & & \\
\hline \multirow[t]{2}{*}{ Aminopeptidase } & F: TCATCAATCGGGCTCAGGTC & 101 & HQ824547.1 & 55 \\
\hline & R: TCCGTTCAGGAAGAGGGTGTT & & & \\
\hline \multirow[t]{2}{*}{ Enteropeptidase } & F: GCCCTGGGTTGTTGCTCTGTAT & 243 & D30799.1 & 55 \\
\hline & R: ATGTCACTGTCCTTTCTCCGTCTG & & & \\
\hline \multirow[t]{2}{*}{ GPR93 } & F: GGTGCTGATGGTGATGGT & 175 & XM_005652601 & 57 \\
\hline & R: GAAGGAAGACAGAGAGTGGGA & & & \\
\hline \multirow[t]{2}{*}{ Lipase } & F: GCTCACGGTCACCATTTCAC & 150 & NM_001177912.2 & 55 \\
\hline & R: TGAGGTAAGGCTCGTGGGAT & & & \\
\hline \multirow[t]{2}{*}{ Carboxypepidase } & F: CCAAGAACCGAATGTGGAGAAA & 222 & NM_214169.1 & 60 \\
\hline & R: TCAGGTATGCTTTGATGGAGGAG & & & \\
\hline \multirow[t]{2}{*}{ Elastase } & F: CTGCTGGTTGTGGACTATGC & 217 & NM_214109.1 & 57 \\
\hline & R: AGGGCTTGTGGTAGTAGTTGC & & & \\
\hline \multirow[t]{2}{*}{ Chymotrypsin } & F: CGGCACCTTAATCACCTCTACTCA & 146 & NM_001244379.1 & 60 \\
\hline & R: CAAAGATGCTATCCACACCCACGA & & & \\
\hline \multirow[t]{2}{*}{ Pepsinogen A } & F: TGTTTCCGTCGAGGGTTACTG & 159 & NM_213873.2 & 60 \\
\hline & R: CCGATGTCGCTCTGGATGTT & & & \\
\hline \multirow[t]{2}{*}{ Progastricsin } & F: TGGCAGATTGGCATTGAGG & 252 & NM_001172999.1 & 59 \\
\hline & R: TGATGGCGACAGAGGGAACT & & & \\
\hline
\end{tabular}

F: forward; R: reverse; $T_{\mathrm{M}}$ : melting temperature

\subsection{Immunohistochemistry}

Fixed tissue samples were washed with PBS and then embedded in paraffin after dehydration with a graded series of ethanol concentrations followed by xylene. Paraffin-embedded tissue sections $(4 \mu \mathrm{m})$ were de-waxed with xylene, ethanol-washed, and re-hydrated with deionized water. After treatment with $3 \%(\mathrm{v} / \mathrm{v}) \mathrm{H}_{2} \mathrm{O}_{2}$ and three washings with $1 \times \mathrm{PBS}$, proteinase $\mathrm{K}$ was used for antigen retrieval followed by three rinses with $1 \times$ PBS and once with cold glycine. Nonspecific binding of antibody protein was blocked with bovine serum albumin. Sections were incubated overnight at $4{ }^{\circ} \mathrm{C}$ with antibodies (AbD, Bio-Rad) against SS and CCK diluted (1:200) in PBS, washed three times with $1 \times$ PBS, then incubated with secondary antibody (AbD, Bio-Rad) diluted (1:250) in PBS. After further washing three times with $1 \times$ PBS, diaminobenzidine (DAB) was used as the chromogen. Sections were counterstained with hematoxylin and examined microscopically. Relative intensity of antigen signals was quantified using Image-pro plus 6.0 software. Statistical analysis of the antigen signals used a pool of at least 6 images.

\subsection{Relative quantification of mRNA expression}

Data are presented as mean \pm standard deviation (SD), with 6 piglets $(n=6)$. Statistical analysis of the difference in mRNA levels was performed by one-way analysis of variance (ANOVA) with Tukey's post hoc test to compare the means. Statistical analyses were performed and the data were analyzed using Prism 6 (Graphpad Software, Inc.). Statistical significance was set at $P<0.05, P<0.01$, and $P<0.001$. 


\section{Results}

\subsection{Effect of dietary CP content on growth per- formance of piglets}

The growth performance of piglets fed different diets was internal and unpublished data. The average daily gain (ADG) and average daily feed intake (ADFI) displayed a similar tendency, but ADG showed a significant increase following raising of the dietary CP level $(P<0.01)$. ADFI in the $20 \%$ and $17 \%$ $\mathrm{CP}$ groups had no significant difference between them but was higher than that in 14\% CP group. Feed to gain $(\mathrm{F} / \mathrm{G})$ ratio in the $20 \% \mathrm{CP}$ group showed a lower level than that in the $14 \%$ and $17 \% \mathrm{CP}$ groups.

\subsection{Effect of dietary CP content on relative ex- pression of genes of selected digestive enzymes in the duodenum, jejunum, and pancreas of piglets}

There were no significant differences $(P>0.05)$ between dietary $\mathrm{CP}$ contents in the expressions of sucrase, glucosidase, or aminopeptidase in the duodenum or jejunum (Figs. 1a, 1b, and 1f). Jejunal expression of amylase exceeded that in the duodenum and was significantly higher in pigs fed $20 \% \mathrm{CP}$ than in either the $14 \%$ or $17 \%$ CP (Fig. 1c); intermediate levels of expression occurred in the pancreas but were unaffected by dietary CP. The expression of maltase showed inconsistent effects of dietary $\mathrm{CP}$ in the duodenum and jejunum; the expression in the $20 \% \mathrm{CP}$ group exceeded that with $17 \% \mathrm{CP}$ in duodenum and reached the highest expression in jejunum when compared with groups fed $14 \%$ or $20 \%$ CP (Fig. 1d). A similar inconsistency in the effect of dietary CP on expression of GPR93 was observed, and the highest expression levels occurred with $17 \% \mathrm{CP}$ in the jejunum but the lowest expression levels in the group with $20 \% \mathrm{CP}$ in duodenum (Fig. 1h). The duodenal expressions of lactase and enteropeptidase exceeded those in the jejunum (Figs. 1e and 1g). The lactase expression declined in the duodenum as the CP increased from $14 \%$ to $20 \%$. The expression of enteropeptidase in the same tissue was greatest with the $17 \%$ CP diet; the highest jejunal expression of lactase occurred with $14 \% \mathrm{CP}$.
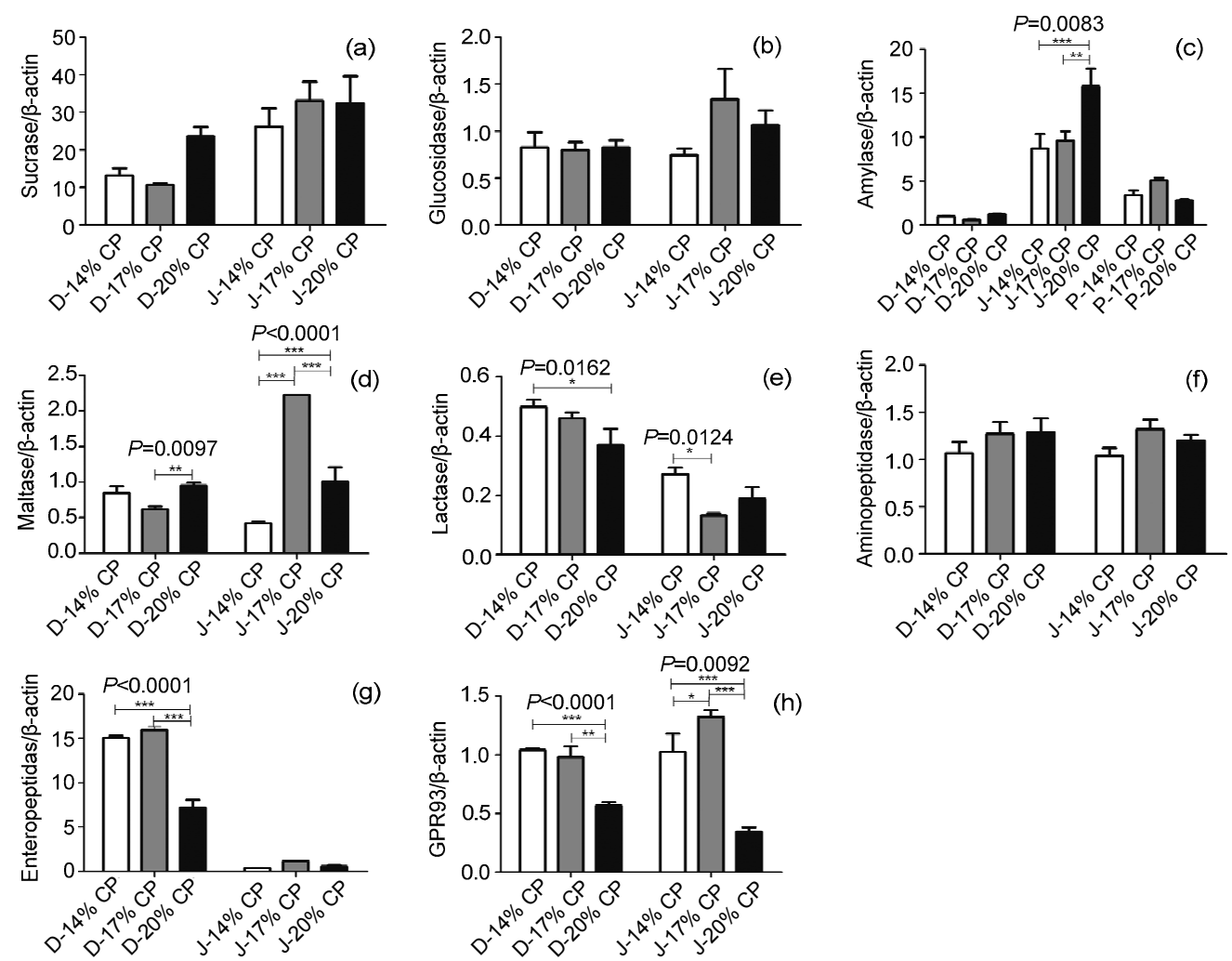

Fig. 1 Relative expression of genes of several enzymes in response to dietary crude protein (CP) levels in duodenum (D), jejunum $(J)$, and pancreas $(P)$ of piglets

(a) Sucrase; (b) Glucosidase; (c) Amylase; (d) Maltase; (e) Lactase; (f) Aminopeptidase; (g) Enteropeptidase; (h) GPR93. Values are expressed as mean \pm SD $(n=6) .{ }^{*} P<0.05,{ }^{* *} P<0.01,{ }^{* * *} P<0.001$, from applying one-way ANOVA followed by Tukey's post hoc tests 
3.3 Effect of dietary $C P$ content on relative expression of selected enzymes in the pancreas and stomach of piglets

In the pancreas, the low $\mathrm{CP}$ diets increased the expression of lipase and the expression of elastase was higher in the $14 \% \mathrm{CP}$ group than in other groups $(P<0.05)$. The lowest levels of expression of lipase, peptidases, carboxypeptidase, and chymotrypsin usually occurred with the $20 \%$ CP diet (Fig. 2). A reversal of the effect of dietary CP on gastric expression of pepsinogen A with 20\% CP giving the highest level was observed (Fig. 2), and lowest expression occurred with $17 \% \mathrm{CP}$. The expression of progastricsin had a similar tendency to that of pepsinogen $\mathrm{A}$, but it showed no significant difference among the CP diets.

\subsection{Effect of dietary CP content on concentrations of $\mathrm{CCK}$, SS, and MLN in piglets}

The antral content of CCK in pigs fed $20 \% \mathrm{CP}$ was significantly lower than that with other CP levels $(P<0.05)$ but there were no differences between diets

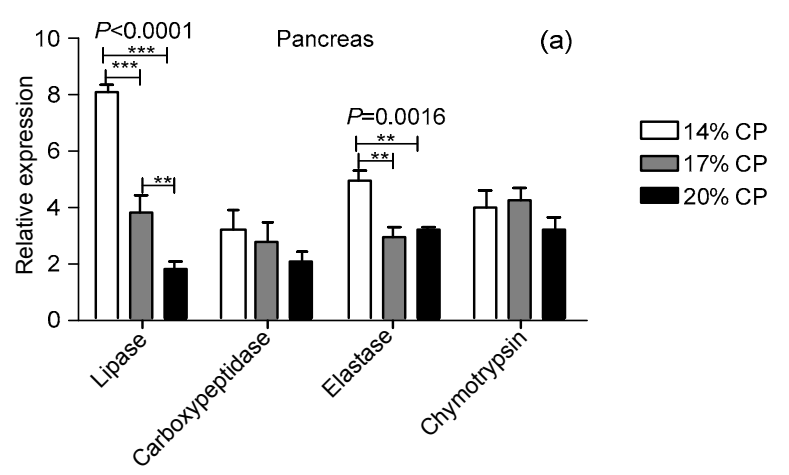

in CCK contents of the duodenum or in plasma (Fig. 3a). The concentrations of SS were significantly higher with the $17 \% \mathrm{CP}$ in gastric antrum but were lower in the duodenum $(P<0.05)$, and did not differ in plasma (Fig. 3b). Concentrations of MLN in the gastric antrum and plasma were higher in pigs fed $14 \%$ $\mathrm{CP}$ than in others and did not differ in the duodenal mucosa (Fig. 3c); there were no significant differences between pigs fed $17 \%$ or $20 \% \mathrm{CP}$.

\subsection{Localization of CCK in the duodenum and SS in the antrum of the stomach}

Immunohistochemical (IHC) localization was consistent with the ELISA data for CCK in the duodenum and SS in the gastric antrum. The quantity of duodenal CCK in pigs fed $17 \% \mathrm{CP}$ exceeded that of the other CP levels, but not significantly so $(P>0.05$; Figs. $4 \mathrm{a}, 4 \mathrm{~b}, 4 \mathrm{c}$, and $4 \mathrm{~g}$ ). Signal intensity of SS in the gastric antrum fed the $17 \% \mathrm{CP}$ diet was significantly greater than that observed in the group fed the $14 \%$ CP diet $(P<0.05$; Figs. 4d, 4e, 4f, and 4g).

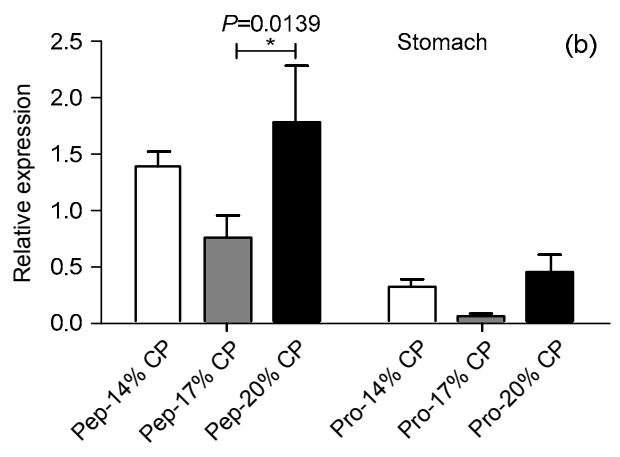

Fig. 2 Effect of dietary crude protein (CP) level on the relative mRNA expression of selected gastric and pancreatic enzymes The pancreatic enzymes involved in fat and protein digestion examined were lipase, carboxypeptidase, elastase, and chymotrypsin (a) and gastric enzymes were pepsinogen A (pep) and progastricsin (pro) (b) among different dietary CP levels (14\%, $17 \%$, and $20 \%$ ). Values are expressed as mean $\pm \operatorname{SD}(n=6) .{ }^{*} P<0.05,{ }^{* *} P<0.01,{ }^{* * *} P<0.001$, from applying one-way ANOVA followed by Tukey's post hoc tests
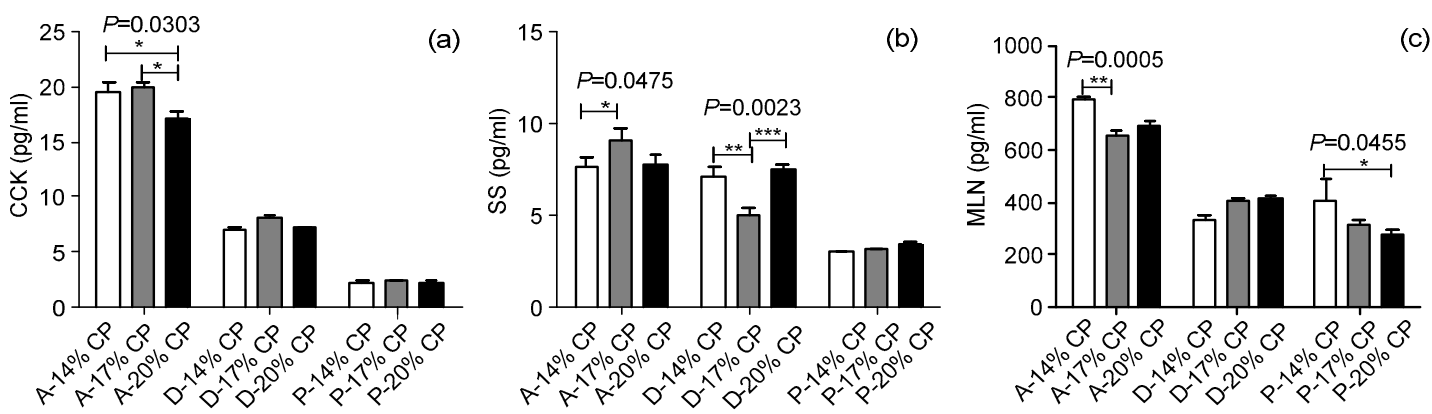

Fig. 3 Concentrations of hormones in plasma (P) and 1:10 supernatants of gastric antrum (A) and duodenum (D) of pigs fed different amounts of dietary crude protein $(\mathrm{CP})$

(a) Cholecystokinin (CCK); (b) Somatostatin (SS); (c) Motilin (MLN). Values are expressed as mean \pm SD $(n=6) .{ }^{*} P<0.05$, ${ }^{* *} P<0.01,{ }^{* * *} P<0.001$, from applying one-way ANOVA followed by Tukey's post hoc tests 

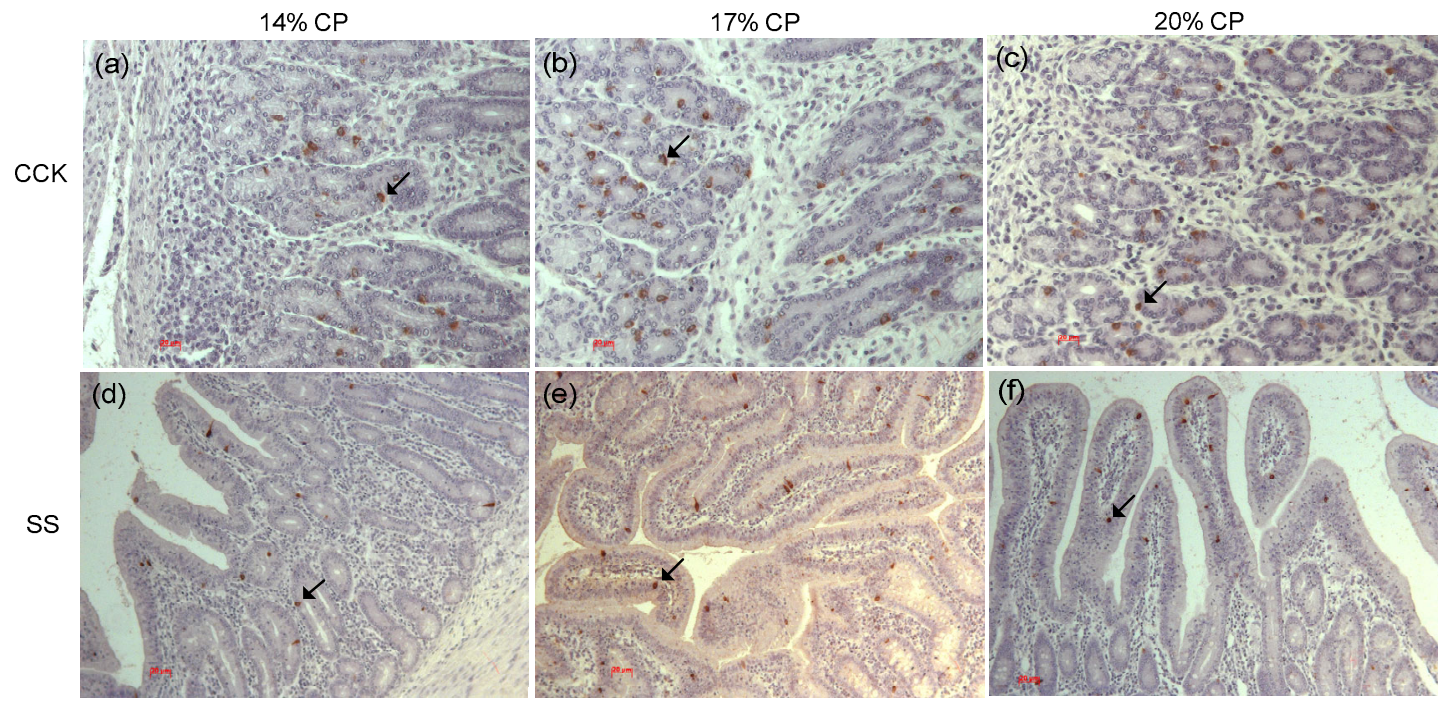

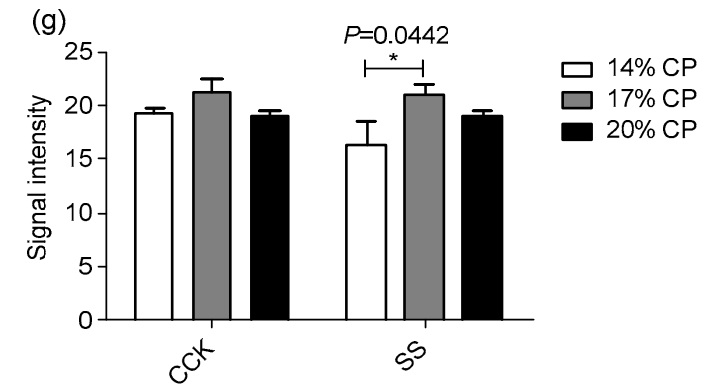

\section{Discussion}

In the context of pig production, maximizing amino acid utilization needs to be balanced with minimizing dietary protein input for environmental, economic, and sanitary reasons. The objective of the present study was to determine an appropriate low protein diet for piglets after weaning. To achieve this objective, diets of different protein content were fed to recently-weaned pigs for $45 \mathrm{~d}$ and selected hormones and transcript abundance of critical enzymes involved in digestion and absorption were investigated in the GIT and pancreas.

Diets with low CP compared with high CP content did not affect performance (le Bellego et al., 2002). It is known that diets with high CP may disturb the intestinal microbiota as a consequence of protein fermentation (Nyachoti et al., 2006; Hermes et al., 2009) and reduced dietary $\mathrm{CP}$, balanced with required amounts of essential amino acids, should reduce $\mathrm{N}$
Fig. 4 Immunohistochemical (IHC) localization of cholecystokinin (CCK) in duodenum and somatostatin (SS) in gastric antrum in pigs fed different levels of crude protein (CP)

(a-c) IHC staining of duodenal CCK; (d-f) IHC staining of antral $\mathrm{SS}$; the brown points represented positive stain (black arrows). (g) Quantification of IHC staining. Relative intensity of antigen signals was quantified by randomly choosing 5 fields per section for image capture and statistical analysis of the number of antigen signals used data from 6 pigs. Values are expressed as mean \pm SD $(n=30) .{ }^{*} P<0.05$, from applying one-way ANOVA followed by Tukey's post hoc test (Note: for interpretation of the references to color in this figure legend, the reader is referred to the web version of this article)

excretion and ammonia emission from swine manure due to fermentation and formation of microbial metabolites (Nyachoti et al., 2006; Htoo et al., 2007). Alternatively, Awati et al. (2006) have proposed reducing protein fermentation in the small intestine by the inclusion of fermentable carbohydrates in the diet. As for carbohydrate digestion, the expressions of sucrase, glucosidase, and amylase had no significant difference among the three dietary CP levels, but the expression of maltase in the $20 \% \mathrm{CP}$ diet was higher than that in the $14 \%$ and $17 \% \mathrm{CP}$ diets in the duodenum. In the jejunum, expression of maltase was higher in the $17 \% \mathrm{CP}$ group than in the others, whereas amylase expression in the jejunum was highest in the piglets fed the $20 \% \mathrm{CP}$ diet. The expression levels of these four enzymes were much higher in the jejunum than in the duodenum and were affected by dietary CP. Jin et al. (1998) reported that low CP diets improved the digestive health of swine, provided that the amino acid requirements are satisfied. 
Hermes et al. (2009) pointed out that low CP diets, supplemented to meet amino acid requirements, can improve the integrity of the gut barrier and reduction in dietary $\mathrm{CP}$ while maintaining the levels of essential amino acids was an effective strategy to minimize post-weaning diarrhea (PWD) in piglets (Barea et al., 2007). A reduction in CP here from $20 \%$ to $17 \%$ enhanced expression of intestinal disaccharidases, presumably favoring more complete digestion and absorption of carbohydrates instead of leaving fermentation substrates in the intestinal lumen.

Barea et al. (2007) showed that decreasing the dietary $\mathrm{CP}$ increased the digestibility and metabolizability of energy. In the present study, reducing the dietary $\mathrm{CP}$ promoted significantly the expression of genes encoding pancreatic digestive enzymes including lipase, enteropeptidase, and elastase, but had no significant effect on the mRNA expression of chymotrypsin, amylase, or carboxypeptidase. However, it did not affect expressions of pepsinogen A and progastricsin in the gastric fundus and, consistent with an earlier finding (Bikker et al., 2006), intestinal expression of aminopeptidase was not affected. Taken together, the results obtained here showed that expression of pancreatic enzymes had an increasing tendency, but expressions of carboxypeptidase and chymotrypsin had no significant difference between pigs fed the $17 \% \mathrm{CP}$ diet and those given the $20 \% \mathrm{CP}$ diet, and expression of lipase in pigs fed $14 \%$ and $17 \% \mathrm{CP}$ diets was significantly higher than that in the $20 \%$ CP diet. Enteropeptidase, from duodenal intestinal glands, cleaves trypsinogen to generate active trypsin, and then activates other pancreatic zymogens including pro-carboxypeptidases, chymotrypsinogen, pro-elastase, and some pro-lipases. The expression of enteropeptidase was highest with the $17 \% \mathrm{CP}$ diet.

The reduction of dietary $\mathrm{CP}$ to $17 \%$ resulted in more CCK in the gastric antrum of the stomach, duodenum, and plasma than the other two diets. CCK can stimulate gallbladder contraction, SS release, and pancreatic growth, and its release of enzymes (Wank, 1995), and is the basis for its older name, pancreozymin. The present research confirmed earlier reports (Green et al., 1986; Leray et al., 2003) that low protein diets enhance CCK release but did not support views (Shi et al., 1997; Hara et al., 2001) that low protein diets inhibited pancreatic enzymes including amylase and protease. However, 17\% dietary CP stimulated gastric generation of SS and CCK while weakening expression of pepsinogen A and progastricsin and reducing intestinal SS release. SS released from the pyloric antrum enters the systemic circulation to reach locations where it will exert its inhibitory effects. In the animals studied here, $17 \%$ dietary CP decreased the quantity of SS in the duodenum and increased that of CCK in the stomach. Williams (2001) explained that CCK appears to be the main hormonal drive for increased zymogen secretion and lipase secretion in response to the presence of fats and amino acids in the intestinal lumen while increased CCK influenced feed intake and decreased SS, effectively accelerating the digestive process (Moran and Kinzig, 2004; Chaudhri et al., 2006), consistent with the present changes in duodenal rather than gastric CCK. Green et al. (1986) discovered that high protein diets increased CCK release and pancreatic protease secretion sufficient to match protein digestive requirement, whereas it was found here that high protein diets decreased CCK and pancreatic protease. It was inferred that CCK likely had a different mechanism in the stomach and intestine, and CCK may mediate food digestion in the stomach by decreasing MLN instead of SS. On the basis of measured hormones and expression of enzymes especially in maltase, enteropeptidase, and lipase, the diet with $17 \% \mathrm{CP}$ appeared to be more beneficial to digestion than $20 \%$ or $14 \%$ CP in these pigs. MLN plays a physiological role as a regulator of gut motility between meals, and there was no significant difference in MLN content between pigs fed $17 \%$ and $20 \%$ dietary $\mathrm{CP}$, though higher levels occurred in the gastric antrum and plasma of pigs fed $14 \%$ CP. Although there was no significant difference in expression of CCK in the small intestine, the expressions of GPR93 and CCK showed a similarity at different dietary CP levels. It is consistent with the known role of GPR93 in inducing CCK transcription and secretion. GPR93 was activated by dietary protein hydrolysate and was subsequently involved in inducing expression of CCK. Expression of CCK in the gastric antrum showed a significant difference from and was higher than that in the small intestine. This demonstrated that dietary CP level mainly affects the expression of CCK in the gastric antrum rather than in the small intestine. GPR93 is a nutrient-responsive, especially to proteins, G protein-coupled receptor (Nilaweera et al., 2010), 
and the present results showed higher expression in pigs fed the $17 \% \mathrm{CP}$ than in pigs fed the $20 \% \mathrm{CP}$ diets. Additionally, peptidases like carboxypeptidase, chymotrypsin, and aminopeptidase in the $17 \% \mathrm{CP}$ group had higher expression than those in other groups, although there were no significant differences. Enteropeptidase also displayed higher expression in the $17 \%$ CP diets compared with $20 \%$ CP diets. The present results are consistent with GPR93 being important in the signaling mechanisms involved in the nutrient induction of the transcription and secretion of bioactive peptidases (Choi et al., 2007). The diet with $17 \% \mathrm{CP}$ was sufficient to meet the requirements for growth, total $\mathrm{N}$ excretion and ammonia emissions, digestion and absorption of nutrient substances, and appeared to be more beneficial than higher or lower $\mathrm{CP}$ to the weaned piglet.

\section{Conclusions}

Considering growth performance, $14 \%$ dietary $\mathrm{CP}$ was not sufficient for meeting the requirement for growth of wean piglet. On the basis of several indices of endocrines and digestive enzymes, this study has shown that, in young weaned pigs, $17 \%$ dietary $\mathrm{CP}$, rather than $14 \%$ or $20 \% \mathrm{CP}$, was beneficial to processes likely to be involved in the digestion of three major nutrient classes: carbohydrates, proteins, and lipids.

\section{Compliance with ethics guidelines}

Zhi-mei TIAN, Xian-yong MA, Xue-fen YANG, Qiu-li FAN, Yun-xia XIONG, Yue-qin QIU, Li WANG, Xiao-lu WEN, and Zong-yong JIANG declare that they have no conflict of interest.

All institutional and national guidelines for the care and use of laboratory animals were followed.

\section{References}

Awati, A., Williams, B.A., Bosch, M.W., et al., 2006. Effect of inclusion of fermentable carbohydrates in the diet on fermentation end-product profile in feces of weanling piglets. J. Anim. Sci., 84(8):2133-2140. http://dx.doi.org/10.2527/jas.2004-676

Barea, R., Nieto, R., Aguilera, J.F., 2007. Effects of the dietary protein content and the feeding level on protein and energy metabolism in Iberian pigs growing from 50 to $100 \mathrm{~kg}$ body weight. Animal, 1(3):357-365. http://dx.doi.org/10.1017/S1751731107666099

Bikker, P., Dirkzwager, A., Fledderus, J., et al., 2006. The effect of dietary protein and fermentable carbohydrates levels on growth performance and intestinal characteristics in newly weaned piglets. J. Anim. Sci., 84(12): 3337-3345.

http://dx.doi.org/10.2527/jas.2006-076

Chaudhri, O., Small, C., Bloom, S., 2006. Gastrointestinal hormones regulating appetite. Philos. Trans. R. Soc. Lond. B Biol. Sci., 361(1471):1187-1209.

http://dx.doi.org/10.1098/rstb.2006.1856

Chen, Y., Hui, H., Yang, H., et al., 2013. Wogonoside induces cell cycle arrest and differentiation by affecting expression and subcellular localization of PLSCR1 in AML cells. Blood, 121(18):3682-3691.

http://dx.doi.org/10.1182/blood-2012-11-466219

Choi, S., Lee, M., Shiu, A.L., et al., 2007. GPR93 activation by protein hydrolysate induces CCK transcription and secretion in STC-1 cells. Am. J. Physiol. Gastrointest. Liver Physiol., 292(5):G1366-G1375. http://dx.doi.org/10.1152/ajpgi.00516.2006

Committee on Nutrient Requirements of Swine, National Research Council, 2012. Nutrient Requirements of Swine, 11th Revised Ed. The National Academies Press, Washington, DC. http://dx.doi.org/10.17226/13298

Green, G.M., Levan, V.H., Liddle, R.A., 1986. Plasma cholecystokinin and pancreatic growth during adaptation to dietary protein. Am. J. Physiol., 251(1 Pt 1):G70-G74.

Hara, H., Ohyama, S., Hira, T., 2001. Endogenous cholecystokinin plays a role in down-regulation of pancreatic amylase independent of dietary carbohydrate in rats. Regul. Pept., 99(2-3):103-110.

He, L., Wu, L., Xu, Z., et al., 2016. Low-protein diets affect ileal amino acid digestibility and gene expression of digestive enzymes in growing and finishing pigs. Amino Acids, 48(1):21-30. http://dx.doi.org/10.1007/s00726-015-2059-1

Hermes, R.G., Molist, F., Ywazaki, M., et al., 2009. Effect of dietary level of protein and fiber on the productive performance and health status of piglets. J. Anim. Sci., 87(11): 3569-3577. http://dx.doi.org/10.2527/jas.2008-1241

Htoo, J.K., Sauer, W.C., Zhang, Y., et al., 2007. The effect of feeding low-phytate barley-soybean meal diets differing in protein content to growing pigs on the excretion of phosphorus and nitrogen. J. Anim. Sci., 85(3):700-705. http://dx.doi.org/10.2527/jas.2006-249

Jahan-Mihan, A., Luhovyy, B.L., el Khoury, D., et al., 2011. Dietary proteins as determinants of metabolic and physiologic functions of the gastrointestinal tract. Nutrients, 3(5):574-603. http://dx.doi.org/10.3390/nu3050574

Jin, C.F., Kim, J.H., Han, I.K., et al., 1998. Effects of supplemental synthetic amino acids to the low protein diets on the performance of growing pigs. Asian Australas. $J$. Anim. Sci., 11(1):1-7. http://dx.doi.org/10.5713/ajas.1998.1

Kendall, D.C., Gaines, A.M., Allee, G.L., et al., 2008. Commercial validation of the true ileal digestible lysine requirement for eleven- to twenty-seven-kilogram pigs. $J$. Anim. Sci., 86(2):324-332. 
http://dx.doi.org/10.2527/jas.2007-0086

le Bellego, L., van Milgen, J., Noblet, J., 2002. Effect of high temperature and low-protein diets on the performance of growing-finishing pigs. J. Anim. Sci., 80(3):691-701.

Len, N.T., Hong, T.T., Ogle, B., et al., 2009. Comparison of total tract digestibility, development of visceral organs and digestive tract of Mong cai and Yorkshire $\times$ Landrace piglets fed diets with different fibre sources. J. Anim. Physiol. Anim. Nutr. (Berl.), 93(2):181-191. http://dx.doi.org/10.1111/j.1439-0396.2007.00804.x

Leray, V., Segain, J.P., Cherbut, C., et al., 2003. Adaptation to low-protein diet increases inhibition of gastric emptying by CCK. Peptides, 24(12):1929-1934. http://dx.doi.org/10.1016/j.peptides.2003.10.015

Lindemann, M.D., Cornelius, S.G., el Kandelgy, S.M., et al., 1986. Effect of age, weaning and diet on digestive enzyme levels in the piglet. J. Anim. Sci., 62(5):1298-1307.

Ling, N., Burgus, R., Rivier, J., et al., 1973. The use of mass spectrometry in deducing the sequence of somatostatina hypothalamic polypeptide that inhibits the secretion of growth hormone. Biochem. Biophys. Res. Commun., 50(1): 127-133.

Lowe, M.E., 1994. Pancreatic triglyceride lipase and colipase: insights into dietary fat digestion. Gastroenterology, 107(5):1524-1536. http://dx.doi.org/10.1016/0016-5085(94)90559-2

Makkink, C.A., Berntsen, P.J., op den Kamp, B.M., et al., 1994. Gastric protein breakdown and pancreatic enzyme activities in response to two different dietary protein sources in newly weaned pig. J. Anim. Sci., 72(11):2843-2850.

Moran, T.H., Kinzig, K.P., 2004. Gastrointestinal satiety signals II. Cholecystokinin. Am. J. Physiol. Gastrointest. Liver Physiol., 286(2):G183-G188. http://dx.doi.org/10.1152/ajpgi.00434.2003

Morisset, J., Wong, H., Walsh, J.H., et al., 2000. Pancreatic CCK(B) receptors: their potential roles in somatostatin release and delta-cell proliferation. Am. J. Physiol. Gastrointest. Liver Physiol., 279(1):G148-G156.

Nilaweera, K.N., Giblin, L., Ross, R.P., 2010. Nutrient regulation of enteroendocrine cellular activity linked to cholecystokinin gene expression and secretion. J. Physiol. Biochem., 66(1):85-92. http://dx.doi.org/10.1007/s13105-010-0012-z

Nyachoti, C.M., Omogbenigun, F.O., Rademacher, M., et al., 2006. Performance responses and indicators of gastrointestinal health in early-weaned pigs fed low-protein amino acid-supplemented diets. J. Anim. Sci., 84(1): 125-134.

Patel, Y.C., 1999. Somatostatin and its receptor family. Front. Neuroendocrinol., 20(3):157-198. http://dx.doi.org/10.1006/frne.1999.0183

Peng, X., Hu, L., Liu, Y., et al., 2016. Effects of low-protein diets supplemented with indispensable amino acids on growth performance, intestinal morphology and immunological parameters in 13 to $35 \mathrm{~kg}$ pigs. Animal, first view. http://dx.doi.org/10.1017/S1751731116000999

Pinheiro, D.F., Pacheco, P.D., Alvarenga, P.V., et al., 2013. Maternal protein restriction affects gene expression and enzyme activity of intestinal disaccharidases in adult rat offspring. Braz. J. Med. Biol. Res., 46(3):287-292.

Shi, G., Leray, V., Scarpignato, C., et al., 1997. Specific adaptation of gastric emptying to diets with differing protein content in the rat: is endogenous cholecystokinin implicated? Gut, 41(5):612-618.

Wank, S.A., 1995. Cholecystokinin receptors. Am. J. Physiol., 269(5 Pt 1):G628-G646.

Williams, J.A., 2001. Intracellular signaling mechanisms activated by cholecystokinin-regulating synthesis and secretion of digestive enzymes in pancreatic acinar cells. Annu. Rev. Physiol., 63:77-97.

http://dx.doi.org/10.1146/annurev.physiol.63.1.77

Wu, L., He, L.Q., Cui, Z.J., et al., 2015. Effects of reducing dietary protein on the expression of nutrition sensing genes (amino acid transporters) in weaned piglets. $J$. Zhejiang Univ.-Sci. B (Biomed. \& Biotechnol.), 16(6): 496-502. http://dx.doi.org/10.1631/jzus.B1400259

Xiao, X., Ross, L.E., Sevilla, W.A., et al., 2013. Porcine pancreatic lipase related protein 2 has high triglyceride lipase activity in the absence of colipase. Biochim. Biophys. Acta, 1831(9):1435-1441. http://dx.doi.org/10.1016/j.bbalip.2013.06.002

Yang, W., Wang, J., Liu, L., et al., 2011. Effect of high dietary copper on somatostatin and growth hormone-releasing hormone levels in the hypothalami of growing pigs. Biol. Trace Elem. Res., 143(2):893-900. http://dx.doi.org/10.1007/s12011-010-8904-x

Yue, L.Y., Qiao, S.Y., 2008. Effects of low-protein diets supplemented with crystalline amino acids on performance and intestinal development in piglets over the first 2 weeks after weaning. Livest. Sci., 115(2-3):144-152. http://dx.doi.org/10.1016/j.livsci.2007.06.018

\section{中文概要}

题 目: 低蛋白日粮对断奶仔猪胃肠道消化酶表达及激素 分泌的影响

目 的: 研究蛋白日粮水平对断奶仔猪消化的影响机制。

创新点: 从营养物质消化及激素变化方面研究低蛋白日粮 对仔猪胃肠道消化吸收的影响, 探究低蛋白日粮 饲养的可行性。

方 法: 18 头 28 日龄断奶仔猪经过 7 天适应期后平均体 重为 $(9.57 \pm 0.64) \mathrm{kg}$ 。仔猪随机分为三组, 每组 6 头, 分别饲喂 $20 \% 、 17 \%$ 和 $14 \%$ 粗蛋白日粮并自 由采食 45 天。根据国家研究委员会 (NRC) 2012 年的标准, 通过添加赖氨酸、蛋氨酸、半胱氨酸、 苏氨酸及色氨酸等理想蛋白模型满足仔猪生长 需求。实验结束后, 进行颈静脉采血并屠宰取样。

结 论: 结果表明基于蛋白日粮水平对内分泌及消化酶影 响, 与 $14 \%$ 及 $20 \%$ 粗蛋白组相比, $17 \%$ 蛋白日粮 更有利于胃肠道和胰腺等组织中三种主要营养 物质的消化。因此, $17 \%$ 粗蛋白水平更适合断奶 仔猪的营养需求, 证实了低蛋白日粮对断奶仔猪 饲养的可行性。

关键词: 日粮蛋白; 仔猪; 胃肠道; 胰腺; 消化; 激素 